\title{
DESAIN MODEL DAN MATERI PEMBELAJARAN BERBASIS TEKNOLOGI INFORMASI
}

\author{
Ali Rahman \\ Email: alirahman@stainparepare.ac.id \\ Institut Agama Islam Negeri (IAIN) Parepare
}

\begin{abstract}
ICT is one of the learning media that is widely used in various fields of education because it increases the effectiveness and efficiency in the learning process. The use of ICT in learning includes tutorials, application tools and communication, while the application of ICT in the world of education is in the form of electronic books and e-learning. The use of information and communication technology in education is absolutely necessary to answer problems in the education sector, especially for access and equity and the quality of education. Everything will run smoothly depending on the technology and network conditions available. Standardization and utilization of ICT in education is very important to ensure the quality of educational processes and outcomes. Teachers as implementers of education are required to design the learning process by presenting the right learning atmosphere so that the learning process can take place effectively, efficiently and pleasantly. One learning model that can be used as a reference for model design and learning based material is the ADDIE model.
\end{abstract}

Keywords: ICT, Education, Learning Model

\begin{abstract}
ABSTRAK
ICT menjadi salah satu media pembelajaran yang banyak digunakan di berbagai bidang pendidikan karena meningkatkan efektifitas dan efisiensi dalam prosem pembelajaran. Penggunaan ICT dalam pembelajaran antara lain sebagai tutorial, alat aolikasi dan komunikasi, sedangkan penerapan ICT dalam dunia pendidikan adalah berupa buku elektronik dan e-learning. Pemanfaatan teknologi informasi dan komunikasi dalam pendidikan mutlak dilakukan untuk menjawab permasalahan di bidang pendidikan terutama akses dan pemerataan serta mutu pendidikan. Semuanya akan berjalan lancar tergantung dengan kondisi teknologi dan jaringan yang tersedia. Standarisasi dan pemanfaatan ICT dalam pendidikan sangat penting untuk menjamin mutu proses dan hasil pendidikan. Guru sebagai
\end{abstract}


pelaksana pendidikan dituntut untuk merancang proses pembelajaran dengan menghadirkan suasana belajar yang tepat agar proses pembelajaran dapat berlangsung secara efektif, efisien dan menyenangkan. Salah satu model pembelajaran yang dapat sebagi acuan desain model dan materi pembelajaran berbasis adalah model ADDIE.

Kata Kunci: ICT, Pendidikan, Model Pembelajaran

\section{PENDAHULUAN}

Memasuki era teknologi informasi dan komunikasi pada saat ini sangat dirasakan pentingnya pemanfaatan TIK dalam kegiatan pembelajaran untuk meningkatkan kualitas pembelajaran yang diharapkan. Teknologi informasi berkembang sejalan dengan perkembangan teori, komunikasi dan teknologi yang menunjang terhadap praktik kegiatan pembelajaran. Pembelajaran berbasis komputer (CBI), Pembelajaran berbasis web (e-learning), Pembelajaran berbantukan komputer (CAI) adalah bentuk pemanfaatan TIK yang perlu dilaksanakan dalam dunia pendidikan saat ini.

Pembelajaran adalah proses interaksi siswa dengan pendidik dan sumber belajar pada suatu lingkungan belajar (UURI No. 20/2003: Sisdiknas Bab I, Pasal 1, ayat 20). Menurut UU Sisdiknas tersebut pembelajaran tidak hanya interaksi antara guru dan siswa tetapi juga melibatkan sumber belajar, jadi siswa tidak hanya memperoleh informasi materi pelajaran dari guru tetapi siswa juga dapat memperoleh dari sumber belajar lain. Dan peran guru disini sebagai fasilitator, mediator yang membuat situasi kondusif untuk terjadinya konstruksi pengetahuan pada diri siswa.

Proses pembelajaran itu tidak hanya sekedar transfer ilmu dari pendidik kepada siswa saja akan tetapi bagaimana pendidikan itu mampu memfasilitasi siswa untuk memiliki ilmu pengetahuan, sikap, kepribadian dan kemandirian. Melakukan proses pendidikan memerlukan banyak pekerjaan dan keterlibatan dari komponen pembelajaran salah satunya adalah guru. Seorang guru dituntut untuk merancang proses pembelajaran dengan menghadirkan suasana belajar yang tepat agar proses pembelajaran dapat berlangsung secara efektif, efisien dan menyenangkan.

Guru sebagai pelaksana pendidikan harus mampu menyiapkan pembelajaran yang tepat melalui model pembelajaran yang sesuai dengan kebutuhan dan kemampuan siswa dengan mempertimbangkan keadaan lingkungan siswa sehingga mencapai kompetensi minimal yang telah ditentukan dan menghadirkan pembaharuasn dalam proses pembelajaran untuk peningkatan mutu pendidikan. 
Untuk mewujudkan hal tersebut, guru dapat menggunakan berbagai model pembelajaran yang dapat merangsang keaktifan siswa dalam proses pembelajaran. ${ }^{1}$ Salah satu model pembelajaran yang dapat digunakan adalah model ADDIE.

Model ADDIE merupakan salah satu model yang dapat menuntun guru secara sistematis untuk merencanakan proses pembelajaran secara efektif. Model ADDIE pada pelaksanaannya memadukan penggunaan teknologi dan media dalam proses pembelajaran. Jadi dengan melakukan perencanaan secara sistematis, dapat membantu memecahkan masalah dan membantu mempermudah menyampaikan pembelajaran. Karena proses pembelajaran itu merupakan proses yang komplek dan merupakan suatu sistem yang perlu dilakukan dengan pendekatan sistematis.

Oleh karena itu, pada makalah ini akan dibahas bagaimana mendesain model dan materi pembelajaran berbasis teknologi informasi dengan menggunakan model ADDIE. Dengan menyiapkan media yang sesuai dengan analisis kebutuhan yang dilakukan sebelum pelaksaan kegiatan pembelajaran.

\section{PEMBAHASAN}

\section{Teori Yang Mendasari Pembelajaran Berbasis Teknologi Informasi}

Ada tiga teori belajar utama sebagai dasar pembelajaran berbasis teknologi informasi, yaitu behaviorisme, kognitivisme dan konstrukstivisme. ${ }^{2}$

\section{Behaviorisme}

Penganut aliran behaviorisme menganggap bahwa belajar adalah perubahan perilaku yang dapat diamati yang disebabkan oleh stimulus eksternal. Mereka melihat pikiran sebagai "kotak hitam", respons terhadap suatu stimulus dapat diamati secara kuantitatif, dengan mengabaikan pengaruh proses berfikir yang terjadi di pikiran. Atkins (1993) menyoroti empat aspek yang relevan untuk merealisasikan materi pembelajaran barbasis teknologi informasi/elearningberkaitan dengan pemikiran behaviorisme, yakni:

a. Bahan ajar sebaiknya dipecah menjadi langkah-langkah instruksional yang dihadirkan secara deduktif, yaitu dimulai dengan rumus, hukum, kategori, prinsip, definisi, dengan memberikan contoh-contoh untuk meningkatkan pemahaman.

b. Perancang harus menetapkan urutan pengajaran dengan menggunakan percabangan bersyarat ke unit instruksional lain. Umumnya, kegiatan diurutkan dari mudah ke sukar atau kompleks.

\footnotetext{
${ }^{1}$ http://sriramadhani2804.blogspot.co.id/2013/05/rancangan-pembelajaran-model-assure_9182.html ${ }^{2}$ Ignasius Fandy Jayanto, "Desain Pembelajaran Berbasis ICT/ E-Learning", http://igfandyjayanto.blogspot.co.id/2012/10/desain-pembelajaran-berbasis-ict-e.html
} 
c. Untuk meningkatkan efisiensi belajar, siswa diminta mengulangi bagian tertentu maupun mengerjakan tes diagnostik. Meskipun demikian, perancang dapat juga mengijinkan siswa memilih pelajaran berikutnya, yang memungkinkan siswa mengontrol proses belajarnya sendiri.

d. Pendekatan behaviorisme menyarankan untuk mendemonstrasikan ketrampilan dan prosedur yang dipelajari. Siswa diharapkan meningkatkan kemahirannya melalui latihan berulang-ulang dengan umpanbalik yang tepat. Pesan-pesan pemberi semangat digunakan untuk meningkatkan motivasi.

Secara keseluruhan, behaviorisme merekomendasi pendekatan terstruktur dan deduktif untuk mendesain bahan ajar, sehingga konsep dasar, ketrampilan, dan informasi faktual dapat cepat diperoleh siswa. Implikasi lebih jauh terhadap pembelajaran berbasis teknologi informasi/e-learning adalah belajar secara drill, memilah-milah bahan ajar, mengases tingkat prestasi, dan memberikan umpanbalik. Tetapi, efektivitas pendekatan desain behaviorisme untuk tugas-tugas berfikir tingkat tinggi masih belum terbukti.

\section{Kognitivisme}

Penganut aliran kognitivisme menganggap bahwa belajar merupakan proses internal yang melibatkan memori, motivasi, refleksi, berfikir, dan meta kognisi. Dalam pandangan aliran tersebut, pikiran manusia memanipulasi simbol-simbol seperti komputer memanipulasi data. Karena itu, siswa dianggap sebagai prosesor informasi. Psikologi kognitif meliputi proses belajar dari pemrosesan informasi, di mana informasi diterima di bermacam-macam indera, ditransfer ke memori jangka pendek dan jangka panjang. Informasi menjalani aliran transformasi dalam pikiran manusia sampai informasi tersebut tersimpan secara permanen di memori jangka panjang dalam bentuk paket-paket pengetahuan. Aliran kognitivisme mengakui pentingnya perbedaan individu dan bermacam-macam strategi belajar untuk mengakomodasi perpedaan tersebut. Gaya belajar yang berbeda-beda (Gardner, 1983; Kolb, 1984) mengacu ke bagaimana siswa menerima. berinteraksi, dan merespons bahan ajar.

Perancang instruksional harus memikirkan aspek-aspek berikut untuk merealisasi materi pembelajaran barbasis teknologi informasi/e-learning, yakni:

a. Strategi pengajaran sebaiknya meningkatkan proses belajar dengan mendayagunakan semua indera, memfokuskan perhatian siswa melalui penekanan pada informasi penting, dan menyesuaian dengan level kognitif siswa. 
b. Perancang instruksional sebaiknya mengaitkan informasi baru dengan informasi lama yang telah ada di memori jangka panjang. Hal ini dapat dilakukan dengan cara memberikan pertanyaan awal untuk mengaktifkan struktur pengetahuan yang diperlukan untuk materi ajar baru.

c. Strategi menerapkan, menganalisis, mensintesis, dan mengevaluasi sebaiknya digunakan untuk menstimulasi belajar level tinggi.

d. Bahan ajar sebaiknya memasukkan aktivitas untuk gaya belajar yang berbedabeda.

e. Siswa perlu dimotivasi untuk belajar melalui strategi belajar yang menstimulasi motivasi intrinsik (berasal dari diri siswa) dan motivasi ekstrinsik (berasal dari guru).

f. Strategi pengajaran sebaiknya mendorong siswa menggunakan ketrampilan meta kognitifnya dengan cara merefleksi apa yang mereka pelajari, berkolaborasi dengan siswa lain maupun memeriksa kemajuan belajar mereka sendiri.

g. Akhirnya, strategi pengajaran sebaiknya menghubungkan materi ajar dengan situasi riil di kehidupan mereka, sehingga siswa dapat mengaitkan pengalaman mereka sendiri.

Secara keseluruhan, perancang instruksional harus memikirkan mulai dari perbedaan aspek-aspek gaya belajar sampai motivasi, kolaborasi maupun meta kognitif. Pendekatan berfokus pada kognitif sesuai untuk mencapai tujuan belajar tingkat tinggi. Kelemahannya adalah jika siswa tidak mempunyai pengetahuan prasyarat.

\section{Konstruktivisme}

Penganut aliran konstruktivisme menganggap bahwa siswa membangun pengetahuannya dari pengalaman belajarnya sendiri. Belajar dapat dilihat sebagai suatu proses yang aktif, dan pengetahuan tidak dapat diterima dari luar mapun dari orang lain. Siswa sebaiknya diberi kesempatan untuk membangun pengetahuan bukan diberi pengetahuan melalui pengajaran. Perancang instruksional harus memikirkan aspek-aspek berikut untuk merealisasi materi pembelajaran barbasis teknologi informasi/e-learning, sebagai berikut:

a. Belajar sebaiknya merupakan proses yang aktif. Siswa diberi kesempatan melakukan aktivitas seperti meminta siswa menerapkan informasi pada situati riil, memfasilitasi penafsiran personal terhadap materi ajar, mendiskusikan topik-topik dalam kelompok. 
b. Untuk mendorong siswa membangun pengetahuan mereka sendiri, guru harus memberikan pengajaran online yang interaktif. Siswa harus mempunyai inisiatif untuk belajar dan berinteraksi dengan siswa lain.

c. Sebaiknya digunakan strategi pembelajaran kolaboratif. Bekerja dengan siswa lain memberikan siswa pengalaman riil dan memperbaiki ketrampilan meta kognitif mereka. Ketika menetapkan siswa-siswa dalam suatu kelompok kerja, keanggotaan sebaiknya didasarkan pada level kemampuan, sehingga setiap anggota dapat mengambil manfaat dari anggota lain.

d. Siswa sebaiknya diberi waktu untuk merefleksikan materi ajar. Pertanyaan pada materi ajar dapat digunakan untuk meningkatkan refleksi.

e. Belajar sebaiknya dibuat bermakna dan ilustratif dengan cara memberikan contoh-contoh dan studi kasus. Di samping itu, aktivitas sebaiknya mendorong siswa menerapkan materi ajar.

f. Ketika belajar memfokuskan pada pengembangan pengetahuan, ketrampilan, dan sikap yang baru, E-Learning menghadapi masalah yaitu tujuan belajar psikomotorik, afektif, dan berfikir tingkat tinggi sulit dicapai dalam fase belajar virtual. Maka disarakan memberikan cara lain seperti aktivitas sosial maupun interaksi dengan siswa lain, belajar berbasis konteks, penilain kinerja untuk mengatasi masalah tersebut.

\section{Pengertian Pembelajaran Berbasis Teknologi Informasi}

ICT (Information and Communication Technology) atau yang lebih dikenal dengan TIK teknologi informasi dan komunikasi) adalah berbagai aspek yang melibatkan teknologi, rekayasa dan teknik pengolahan yang digunakan dalam pengendalian dan pemrosesan informasi serta penggunaannya, hubungan computer dengan manusia dan hal yang berkaitan dengan social, ekonomi dan kebudayaan. Pengertian lainnya diungkapkan bahwa teknologi informasi dan komunikasi adalah studi atau penggunaan peralatan elektronika terutama computer, untuk menyimpan, menganalisis dan mendistribusikan informasi apa saja,termasuk kata-kata, bilangan dan gambar. ${ }^{3}$

Dengan demikian, TIK mencakup dua aspek, yaitu teknologi informasi dan teknologi komunikasi. Teknologi informasi meliputi segala hal yang berkaitan dengan proses, penggunaan sebagai alat bantu, manipulasi, dan pengelolaan informasi. Sedangkan teknologi komunikasi adalah segala sesuatu yang berkaitan dengan penggunaan alat bantu untuk memproses dan mentransfer data dari perangkat yang satu ke lainnya. Jadi Teknologi Informasi dan Komunikasi

\footnotetext{
${ }^{3}$ http://www.madrasahmedia.web.id/2015/03/pembelajaran-berbasis-ict-tik.html
} 
mengandung pengertian luas yaitu segala kegiatan yang terkait dengan pemrosesan, manipulasi, pengelolaan, pemindahan informasi antar media.

Dalam menghadirkan fungsi teknologi asas praktis, efektif dan efisien menjadi acuan utama. Artinya kalau kehadirannya justru menyulitkan dan menambah beban materi dan waktu maka kehadiran TIK justru tidak ada gunanya. Namun rasanya hal ini tidak akan terjadi di era informasi ini. Di mana perangkat komunikasi nirkabel sudah merambah sampai ke pelosok pedesaan. Kehadiran teknologi ini harus digunakan sebaik-baiknya dengan pengelolaan yang tepat.

\section{Prinsip-prinsip Pembelajaran Berbasis Teknologi Informasi}

Prinsip umum penggunaan teknologi informasi, dalam hal ini ICT adalah sebagai berikut:

1. Efektif dan efisien. Penggunaan ICT harus memperhatikan manfaat dari teknologi ini dalam hal mengefektifkan belajar, meliputi pemerolehan ilmu, kemudahan dan keterjangkauan, baik waktu maupun biaya.

2. Optimal. Dengan menggunakan ICT, paling tidak pembelajaran menjadi bernilai "lebih" daripada tanpa menggunakannya. Nilai lebih yang diberikan ICT adalah keluasan cakupan, kekinian (up to date), kemodernan dan keterbukaan.

3. Menarik. Artinya dalam prinsip ini, pembelajaran dikelas akan lebih menarik dan memancing keingintahuan yang lebih. Pembelajaran yang tidak menarik dan memancing keingintahuan yang lebih akan berjalan membosankan dan kontra produktif untuk pembelajaran.

4. Merangsang daya krativitas berpikir pelajar. Dengan menggunakan ICT tentu saja diharapkan pelajar mampu menumbuhkan kreativitasnya dengan maksimal yang terdapat didalam diri mereka. Seorang anak yang mempunyai kreativitas tinggi tentunya berbeda dengan pelajar yang mempunyai kreativitas rendah. Pelajar yang mempunyai kreativitas tinggi tentunya akan mampumenyelesaikan permasalahan dengan cepat dan tanggap terhadap permasalahan yang muncul. Begitu pula sebaliknya dengan pelajar yang berkreativitas rendah. ${ }^{4}$

Dengan demikian, tujuan ICT akan sejalan dengan tujuan pendidikan itu sendiri ketika digunakan dalam pembelajaran. Penggunaan ICT tidak justru menjadi penghambat dalam pembelajaran namun akan memberi manfaat yang lebih dalam pembelajaran.

\footnotetext{
${ }^{4}$ Ibid.
} 


\section{Aplikasi Pembelajaran Berbasis Teknologi Informasi}

Pada saat ini, pembelajaran ICT di lingkungan sekolah/universitas merupakan hal yang sangat penting. Hal ini dikarenakan semakin meningkatnya kebutuhan informasi dan komunikasi dalam berbagai keperluan seiring dengan perkembangan ilmu pengetahuan dan teknologi (IPTEK). ICT yang secara sederhana disimbolkan oleh perangkat computer dan jaringan internet serta perangkat komunikasi telah banyak dimanfaatkan untuk meningkatkan produktivitas kerja para pelajar mulai dari sekolah dasar hingga perguruan tinggi.

Satu bentuk produk TIK yang sedang menjadi "trend" adalah internet yang berkembang pesat di penghujung abad ke-20 dan di ambang abad ke-21. Kehadiran internet telah memberikan dampak yang cukup besar terhadap kehidupan umat manusia dalam berbagai aspek dan dimensi. Internet merupakan salah satu instrumen dalam era globalisasi yang telah menjadikan dunia ini menjadi transparan dan terhubungkan dengan sangat mudah dan cepat tanpa mengenal batas-batas kewilayahan atau kebangsaan. Melalui internet setiap orang dapat berkomunikasi. Bahkan, dunia pendidikan pun tidak luput untuk memanfaatkannya sehingga kelas maya dapat tercipta.

Hal yang paling mutakhir adalah berkembangnya apa yang disebut "cyber teaching" atau pengajaran maya, yaitu proses pengajaran yang dilakukan dengan menggunakan internet. Istilah lain yang makin populer saat ini ialah e-learning yaitu satu model pembelajaran dengan menggunakan media TIK khususnya internet. Dengan e-learning memungkinkan terjadinya proses belajar mengajar jarak jauh. E-learning merupakan dasar dari perkembangan teknologi informasi dan komunikasi. Dengan e-learning, peserta didik tidak perlu duduk dengan manis di ruang kelas untuk menyimak setiap ucapan dari seorang guru secara langsung. $E$ learning juga dapat mempersingkat jadwal target waktu pembelajaran dan tentu saja menghemat biaya yang harus dikeluarkan oleh sebuah program pembelajaran.

E-learning mempermudah interaksi antara peserta didik dengan materi, peserta didik dengan pengajar maupun sesame peserta didik. Peserta didik dapat saling tukar informasi dan dapat mengakses bahan-bahan belajar setiap saat dan berulang-ulang. Dengan kondisi yang demikian itu peserta didik dapat lebih memantapkan penguasaanya terhadap materi pembelajaran.

Selain e-learning, potensi TIK dalam pembelajaran di sekolah dapat juga memanfaatkan e-laboratory dan e-library. Adanya laboratorium virtual (virtual lab) memungkinkan guru dan siswa dapat belajar menggunakan alat-alat laboratorium atau praktikum tidak di laboratorium secara fisik, tetapi dengan menggunakan media computer. Perpustakaan elektronik (e-library) sekarang ini 
sudah menjangkau berbagai sumber buku yang tak terbatas untuk bisa diakses tanpa harus membeli buku/sumber belajar tersebut.

Beberapa aplikasi teknologi informasi dan komunikasi dalam pengembangan pembelajaran yang dapat dikembangkan antara lain: ${ }^{5}$

\section{Pembelajaran Berbasis Komputer}

Pembelajaran berbasis computer yaitu penggunaan computer sebagai alat bantu dalam dunia pendidikan dan pengajaran. Penggunaan computer secara langsung denga peserta didik untuk menyampaikan isi pelajaran, memberikan latihan dan mengevaluasi kemajuan belajar peserta didik. Materi pembelajaran dibuat dalam bentuk powerpoint atau CD pembelajaran interaktif.

Pembelajaran berbasis computer merupakan program pembelajaran yang digunakan dalam proses pembelajaran dengan menggunakan software computer (CD pembelajaran) berupa program computer yang berisi tentang judul, tujuan, materi pembelajaran dan evaluasi pembelajaran.

\section{E-Learning}

E-Learning adalah pembelajaran terintegrasi/terpadu dengan menggunakan jaringan internet (network), intranet (LAN), atau ekstranet (WAN) sebagai pengantar materi, interaksi atau fasilitas. E-Learning disebut juga online learning. Pada pembelajaran model ini pembelajaran dapat disajikan dalam format, yaitu:

a. e-mail (pengajar dan peserta didik berinteraksi dalam pembelajaran dengan menggunakan fasilitas $e$-mail,

b. mailing list/grup diskusi, bisa menggunakan fasilitas e-mail atau fasilitas jejaring social seperti facebook atau twitter,

c. mengunggah bahan ajar dari internet, peserta didik dapat mencari bahan ajar melalui internet untuk menambah pengetahuan tentang pokok bahasan yang sedang dipelajari,

d. pembelajaran interaktif melalui web/blog, (5) interactive conferencing, berupa pembelajaran langsung jarak jauh.

\section{Pembelajaran Berbasis Web}

Sekolah harus menyediakan/membuat website sekolah yang di antaranya berisi materi-materi pelajaran. Setiap pengajar harus memiliki blog sendiri yang berisi mata pelajaran yang diajarkan, bisa berkomunikasi tentang materi pelajaran dengan peserta didik di dunia maya, dengan demikian akan tercipta virtual class room (kelas dunia maya) yang dapat memotivasi dan menambah wawasan pengetahuan peserta didik.

\footnotetext{
${ }^{5}$ Ibid.
} 


\section{Penilaian Berbasis TIK}

Penilaian hasil belajar peserta didik memerlukan pengolahan dan analisis yang akurat, obyektif, transparan dan integral agar bisa dipertanggungjawabkan. Oleh karena itu, perlu dikembangkan penilaian berbasis computer yang bisa diakses oleh peserta didik, pengajar dan orang tua.

\section{Perpustakaan Online}

Sumber belajar pokok bagi peserta didik adalah buku-buku pelajaran dan buku-buku referensi yang lengkap. Buku-buku tersebut biasanya ada di perpustakaan sekolah. Semakin banyaknya buku dan banyaknya peserta didik yang memanfaatkan perpustakaan, membutuhkan manajemen perpustakaan yang baik. Salah satu strategi pelayanan perpustakaan berbasis computer adalah perpustakaan online. Perpustakaan online adalah fasilitas perpustakaan dalam dunia digital yang ada di internet yang memungkinkan seseorang dapat mengakses ke segala sumber ilmu pengetahuan dengan cara yang mudah tanpa adanya batasan waktu dan jarak.

\section{Manfaat Pembelajaran Berbasis Teknologi Informasi}

Manfaat pembelajaran berbasis teknologi informasi terdiri atas empat hal, yaitu:

1. Meningkatkan kadar interaksi pembelajaran antara peserta didik dengan guru atau instruktur (enhance interactivity).

2. Memungkinkan terjadinya interaksi pembelajaran dari mana dan kapan saja (time and place flexibility).

3. Menjangkau peserta didik dalam cakupan yang luas (potential to reach a global audience).

4. Mempermudah penyempurnaan dan penyimpanan materi pembelajaran (easy updating of content as well as archivable capabilities). ${ }^{6}$

\section{Karakteristik Pembelajaran Berbasis Teknologi Informasi}

Karakteristik pembelajaran berbasis internet antara lain adalah penyajian materi pembelajaran dilakukan dengan menayangkan objek-ajar secara tekstual maupun audio-visual. Teknologi komputer dan jaringan internet saat ini telah memungkinkan penayangan materi pembelajaran secara audio-visual dengan kualitas cukup tinggi.

1. Materi pembelajaran disajikan dalam potongan-potongan kecil yang dapat ditayangkan satu layar penuh atau video/audio dengan masa tayang 5-10 menit. Ada alasan teknis, psikologis, dan alasan ergonomis yang menentukan ukuran potogan-potongan materi pembelajaran tersebut. Potongan kecil teks

\footnotetext{
${ }^{6}$ Ignasius Fandy Jayanto, op.cit.
} 
(dengan tayangan kira-kira satu layar penuh tanpa harus menggulung layar) memungkinkan pengiriman file secara cepat. Demikian juga potongan audio/video dengan durasi 5-10 menit memungkinkan siswa tidak terlalu lama menunggu proses pengunduhannya (downloading). Dari sisi ergonomika, penayangan teks utuh tanpa harus menggulung layar membuat mata menjadi lebih nyaman. Siswa cenderung mencetak terlebih dahulu materi ajar yang disajikan terlalu panjang (lebih dari 3 halaman tayangan) sebelum membacanya.

2. Siswa dimungkinkan belajar dengan kecepatan sesuai kebutuhan dan kemampuan, serta dapat mengakses materi pembelajaran secara non-linier. Karakteristik ini berbeda dengan pembelajaran konvensional di mana siswa maju bersama seiring dengan panduan yang diberikan oleh fasilitator. Terkait dengan ini, perancang materi pembelajaran harus memberikan sarana interaktivitas antara siswa dengan objek-ajar yang memungkinkan siswa mengakses bahan ajar secara non-linier.

3. Interaksi antara siswa dengan fasilitator (guru/dosen) umumnya berlangsung secara asinkron, kecuali bila digunakan fasilitas chatting atau tele/video conference. Hampir semua perangkat lunak course/learning management system (misalnya: WebCT, Moodle, Claroline, dan sebagainya) menggunakan sarana komunikasi asinkron berupa email atau internal mail (Wibawanto, 2006) dan internal chat. Disebut internal mail dan internal chat karena fasilitas itu hanya dapat diakses apabila siswa masuk ke dalam situs (log-in).

4. Diskusi berlangsung secara tekstual, menggunakan fasilitas mirip mailing list yang hanya berlaku internal (di dalam situs pembelajaran, sehingga siswa perlu log-in terlebih dahulu sebelum bergabung). Mekanismenya seperti mekanisme berkirim surat elektronik (email). Pendapat/pertanyaan diberikan kepada seluruh komunitas (siswa, fasilitator, dan administrator) melalui email ke alamat discussion forum. Tanggapan juga diberikan oleh anggota komunitas melalui email ke alamat discussion forum. ${ }^{7}$

\section{Desain Model dan Materi Pembelajaran Berbasis Teknologi Informasi dengan Model ADDIE}

Model ADDIE adalah salah satu model desain sistem pembelajaran yang memperlihatkan tahapan-tahapan dasar sistem pembelajaran yang sederhana

\footnotetext{
${ }^{7}$ Ibid.
} 
dan mudah dipelajari. ${ }^{8}$ Model ini terdiri atas lima tahap utama, yaitu: Analyze; Design; Develop; Implement; dan Evaluate. ${ }^{9}$

\section{Analisis}

Analisis merupakan langkah pertama dari model desain sistem pembelajaran ADDIE. Langkah analisis melalui dua tahap yaitu:

a. Analisis Kinerja

Analisis kinerja dilakukan untuk mengetahui dan mengklarifikasi apakah masalah kinerja yang dihadapi memerlukan solusi berupa penyelenggaraan program pembelajaran atau perbaikan manajemen.

Contoh:

1) Kurangnya pengetahuan dan ketrampilan menyebabkan rendahnya kinerja individu dalam organisasi atau perusahaan, hal ini diperlukan solusi berupa penyelenggaraan program pembelajaran.

2) Rendahnya motivasi berprestasi, kejenuhan, atau kebosanan dalam bekerja memerlukan solusi perbaikan kualitas manajemen.Misalnya pemberian insentif terhadap prestasi kerja, rotasi dan promosi, serta penyediaan fasilitas kerja yang memadai.

b. Analisis Kebutuhan

Analisis kebutuhan merupakan langkah yang diperlukan untuk menentukan kemampuan-kemampuan atau kompetensi yang perlu dipelajari oleh siswa untuk meningkatkan kinerja atau prestasi belajar. Hal ini dapat dilakukan apabila program pembelajaran dianggap sebagai solusi dari masalah pembelajaran yang sedang dihadapi.Pada saat seorang perancang program pembelajaran melakukan tahap analisis, ada dua pertanyaan kunci yang yang harus dicari jawabannya, yaitu:

1) Apakah tujuan pembelajaran yang telah ditentukan, dibutuhkan oleh siswa?

2) Apakah tujuan pembelajaran yang telah ditentukan, dapat dicapai oleh siswa?

Jika hasil analisis data yang telah dikumpulkan mengarah kepada pembelajaran sebagai solusi untuk mengatasi masalah pembelajaran yang sedang dihadapi, selanjutnya perancang program pembelajaran melakukan analisis kebutuhan dengan cara menjawab beberapa pertanyaan lagi.

Pertanyaannya sebagai berikut:

a) Bagaimana karakteristik siswa yang akan mengikuti program pembelajaran? (learner analysis)

\footnotetext{
${ }^{8}$ http://tiarablogadders.blogspot.co.id/2015/11/tahapan-desain-bahan-ajar-multimedia.html

${ }^{9}$ Robert Maribe Branch, Instructional Design: The ADDIE Approach, (New York: Springer, 2009), h. 23-163.
} 
b) Pengetahuan dan ketrampilan seperti apa yang telah dimiliki oleh siswa? (prerequisite skills)

c) Kemampuan atau kompetensi apa yang perlu dimiliki oleh siswa? (task atau goal analysis)

d) Apa indikator atau kriteria yang dapat digunakan untuk menentukan bahwa siswa telah mencapai kompetensi yang telah ditentukan setelah melakukan pembelajaran? (evaluation and assessment)

e) Kondisi seperti apa yang diperlukan oleh siswa agar dapat memperlihatkan kompetensi yang telah dipelajari? (setting or condition analysis)

\section{Desain}

Desain merupakan langkah kedua dari model desain sistem pembelajaran ADDIE. Langkah ini merupakan:

a. Inti dari langkah analisis karena mempelajari masalah kemudian menemukan alternatif solusinya yang berhasil diidentifikasi melalui langkah analisis kebutuhan.

b. Langkah penting yang perlu dilakukan untuk, menentukan pengalaman belajar yang perlu dimilki oleh siswa selama mengikuti aktivitas pembelajaran.

c. Langkah yang harus mampu menjawab pertanyaan, apakah program pembelajaran dapat mengatasi masalah kesenjangan kemampuan siswa? Kesenjangan kemampuan disini adalah perbedaan kemampuan yang dimilki siswa dengan kemampuan yang seharusnya dimiliki siswa.

Contoh pernyataan kesenjangan kemampuan:

1) Siswa tidak mampu mencapai standar kompetensi yang telah ditentukan setelah mengikuti proses pembelajaran.

2) Siswa hanya mampu mencapai tingkat kompetensi $60 \%$ dari standar kompetensi yang telah digariskan.

Pada saat melakukan langkah ini perlu dibuat pertanyaan-pertanyaan kunci di antaranya adalah sebagai berikut:

a) Kemampuan dan kompetensi khusus apa yang harus dimilki oleh siswa setelah menyelesaikan program pembelajaran?

b) Indikator apa yang dapat digunakan untuk mengukur keberhasilan siswa dalam mengikuti program pembelajaran.

c) Peralatan atau kondisi bagaimana yang diperlukan oleh siswa agar dapat melakukan unjuk kompetensi - pengetahuan, ketrampilan, dan sikap - setelah mengikuti program pembelajaran? 
d) Bahan ajar dan kegiatan seperti apa yang dapat digunakan dalam mendukung program pembelajaran?

\section{Pengembangan}

Pengembangan merupakan langkah ketiga dalam mengimplementasikan model desain sistem pembelajaran ADDIE. Langkah pengembangan meliputi kegiatan membuat, membeli, dan memodifikasi bahan ajar. Dengan kata lain mencakup kegiatan memilih, menentukan metode, media serta strategi pembelajaran yang sesuai untuk digunakan dalam menyampaikan materi atau substansi program.

Dalam melakukan langkah pengembangan, ada dua tujuan penting yang perlu dicapai, antara lain:

a. Memproduksi, membeli, atau merevisi bahan ajar yang akan digunakan untuk mencapai tujuan pembelajaran yang telah dirumuskan sebelumnya.

b. Memilih media atau kombinasi media terbaik yang akan digunakan untuk mencapai tujuan pembelajaran.

Pada saat melakukan langkah pengembangan, seorang perancang akan membuat pertanyaan-pertanyaan kunci yang harus dicari jawabannya, Pertanyaanpertanyaannya antara lain:

a) Bahan ajar seperti apa yang harus dibeli untuk dapat digunakan dalam mencapai tujuan pembelajaran?

b) Bahan ajar seperti apa yang harus disiapkan untuk memenuhi kebutuhan siswa yang unik dan spesifik?

c) Bahan ajar seperti apa yang harus dibeli dan dimodifikasi sehingga dapat digunakan untuk memenuhi kebutuhan siswa yang unik dan spesifik?

d) Bagaimana kombinasi media yang diperlukan dalam menyelenggarakan program pembelajaran?

\section{Implementasi}

Implementasi atau penyampaian materi pembelajaran merupakan langkah keempat dari model desain sistem pembelajaran ADDIE. Tujuan utama dari langkah ini antara lain:

a. Membimbing siswa untuk mencapai tujuan atau kompetensi.

b. Menjamin terjadinya pemecahan masalah/solusi untuk mengatasi kesenjangan hasil belajar yang dihadapi oleh siswa.

c. Memastikan bahwa pada akhir program pembelajaran, siswa perlu memilki kompetensi, pengetahuan, ketrampilan, dan sikap yang diperlukan. 
Pertanyaan-pertanyaan kunci yang harus dicari jawabannya oleh seorang perancang program pembelajaran pada saat melakukan langkah implementasi yaitu sebagai berikut:

a) Metode pembelajaran seperti apa yang paling efektif utnuk digunakan dalam penyampaian bahan atau materi pembelajaran?

b) Upaya atau strategi seperti apa yang dapat dilakukan untuk menarik dan memelihara minat siswa agar tetap mampu memusatkan perhatian terhadap penyampaian materi atau substansi pembelajaran yang disampaikan?

\section{Evaluasi}

Evaluasi merupakan langkah terakhir dari model desain sistem pembelajaran ADDIE. Evaluasi adalah sebuah proses yang dilakukan untuk memberikan nilai terhadap program pembelajaran. Evaluasi terhadap program pembelajaran bertujuan untuk mengetahui beberapa hal, yaitu:

a. Sikap siswa terhadap kegiatan pembelajaran secara keseluruhan.

b. Peningkatan kompetensi dalam diri siswa, yang merupakan dampak dari keikutsertaan dalam program pembelajaran.

c. Keuntungan yang dirasakan oleh sekolah akibat adanya peningkatan kompetensi siswa setelah mengikuti program pembelajaran.

Beberapa pertanyaan penting yang harus dikemukakan perancang program pembelajaran dalam melakukan langkah-langkah evaluasi, antara lain:

a) Apakah siswa menyukai program pembelajaran yang mereka ikuti selama ini?

b) Seberapa besar manfaat yang dirasakan oleh siswa dalam mengikuti program pembelajaran?

c) Seberapa jauh siswa dapat belajar tentang materi atau substansi pembelajaran?

d) Seberapa besar siswa mampu mengaplikasikan pengetahuan, ketrampilan, dan sikap yang telah dipelajari?

e) Seberapa besar kontribusi program pembelajaran yang dilaksanakan terhadap prestasi belajar siswa?

\section{KESIMPULAN}

Satu bentuk produk TIK yang sedang menjadi "trend" adalah internet Kehadiran internet telah memberikan dampak yang cukup besar terhadap kehidupan umat manusia dalam berbagai aspek dan dimensi. Hal yang paling mutakhir adalah berkembangnya apa yang disebut "cyber teaching" atau pengajaran maya, yaitu proses pengajaran yang dilakukan dengan menggunakan internet. E-learning mempermudah interaksi antara peserta didik dengan materi, peserta didik dengan pengajar maupun sesame peserta didik. 
Model pembelajaran ADDIE merupakan suatu model yang sistematis tahapantahapan ddalam model pembelajaran ADDIE harus dilakukan secara terstruktur dan berurutan, model pembelajaran ADDIE merupakan model pembelajaran yang mengidentifikas siswa secara mendalam hal ini dimaksudkan agar siswa dapat mencapai kompetensi yang diharapkan.

Pembelajaran model ADDIE merupakan pembelajaran yang berfokus pada siswa, dalam hal ini penulis menyarankan akselerasi antara pendidik dan siswa perlu ditambahkan dalam model pembelajaran ini. Guna akselerasi yaitu untuk menciptkan suatu ketergantungan antara pendidik dan siswa artinya siswa dan pendidik merasa saling ketergantungan antara satu sama lain. Guna lain juga, agar terciptanya pembelajaran yang efektif yaitu pembelajaran yang bersifat kolaborasi antara teacher centre dan student centre.

\section{DAFTAR PUSTAKA}

Branch, Robert Maribe, Instructional Design: The ADDIE Approach, New York: Springer, 2009.

Jayanto, Ignasius Fandy, "Desain Pembelajaran Berbasis ICT/E-Learning", http://igfandyjayanto.blogspot.co.id/2012/10/desain-pembelajaran-berbasisict-e.html

http://sriramadhani2804.blogspot.co.id/2013/05/rancangan-pembelajaran-modelassure_9182.html

http://www.madrasahmedia.web.id/2015/03/pembelajaran-berbasis-ict-tik.html http://tiarablogadders.blogspot.co.id/2015/11/tahapan-desain-bahan-ajarmultimedia.html 